\title{
Khalwatiyah Samman: Strategies for Strengthening Modality in the Patte'ne Maros Community of Sulawesi Selatan
}

\author{
Nurlela* \\ Department of Antropology Education \\ Faculty of Social Science \\ Universitas Negeri Makassar \\ Makassar, Indonesia \\ nurlela@unm.ac.id
}

\author{
Jumadi \\ Departemen of Sociological Science \\ Faculty of Social Science \\ Universitas Negeri Makassar \\ Makassar, Indonesia \\ jumadi@unm.ac.id
}

\author{
Abdul Rahman \\ Department of Antropology Education \\ Faculty of Social Science \\ Universitas Negeri Makassar \\ Makassar, Indonesia \\ abdul.rahman8304@unm.ac.id
}

\begin{abstract}
This study aims to map the influence of modality (economic, social, cultural, and symbolic) and analyze modalities strengthening strategies (biological investment strategy; successive; educational; invasion / economic capital; and symbolic investment) in the community adhering to the Khalwatiyah Samman Tarekat in Patte'ne. Marusu, Maros Regency, Sulawesi Selatan. This type of research is qualitative, using qualitative descriptive analysis. The research subjects were the leader (khalifah) and the followers of Khalwatiyah Samman who were selected by purposive sampling. The focus of the research is the modalities and strategies for strengthening modalities in the community of Tarekat Khalwatiyah Samman in Patte'ne Marusu, Maros Regency, Sulawesi Selatan. The main research instrument is the researcher himself. Data collection was carried out through observation, in-depth interviews, documentation, and research instruments to collect data related to modalities and strategies for strengthening modalities in society. Data analysis begins with a heuristic process (collecting data), critique or verification/validation of data, interpretation and writing of facts (historiography). The results showed that social modality is the main determinant of modality in addition to cultural, economic, and symbolic modalities. Religious symbolic investment supported by biological, educational, and successive investments is a determining factor in strengthening the modalities strategy of the Khalwatiyah Samman Order.
\end{abstract}

Keywords: Khalwatiyah Samman, Modalities, and Strategies for Strengthening Modality

\section{I.}

\section{INTRODUCTION}

Khalwatiyah Samman is the name of the Tarekat based in Patte'ne Marusu, Maros Regency, Sulawesi Selatan. Khalwatiyah comes from the name of a 17th century Sufi warrior ulama from Makassar, namely Sheikh Yusuf AlMakassari Al-Khalwati (tabarruk) against Muhammad (Nur) Al-Khalwati Al Khawa Rizmi. The Khalwatiyah Samman Order is taken from the name of an 18th century Medina Sufi Muhammad Al-Samman. The Khalwatiyah Samman Order is known to be very centralistic (centralized) in its leadership. The teacher (caliph) submits to the central leadership who is in Patte'ne Marusu, Maros Regency, Sulawesi Selatan. The local chapters of the Khalwatiyah Samman Tarekat have their own places of worship (mosque, mushalla or langgar) and there is a tendency to isolate themselves from other tarekat followers but remain populist in terms of style and social composition and most of their followers are village people.

The peeling of the modalities and the strategy of strengthening the modalities of the Khalwatiyah Samman Order to survive and have so many followers is associated with the concept of Bourdieu's modality strengthening strategy. Strategy plays a very important role in an arena, according to Bourdieu [1], [2] In an arena there are always parties, both individuals and groups who dominate with the power of their own capital, those who are not groups dominate, must strive so that capital owned can survive, develop, and then can be preserved.

Modality determines the reproduction of the instruments contained in the arena whose distribution forms the structure of the arena and has power over the patterns and regularities that govern the work of the arena, so that actors can use as a force (to defend and even seize) the position of actors in the arena; symbolic capital allows the agent to strengthen his position in the eyes of society. Bourdieu also introduced the concept of symbolic power, doxa, orthodoxy, and heterodoxy, namely the power to maintain or change the objective principles of union or separation, association or dissociation, the power to maintain or change various classifications; power describes individuals, groups or institutions through words, and power to define situations, where interactions take place which are determined by symbolic capital in reality. Based on the background of the problem (problem statement), the main problem of this research is what modalities and strategies to strengthen the modalities owned by the Caliph and the community followers of the Khalwatiyah Samman Tarekat which is centered in Patte'ne Marusu, Maros Regency, Sulawesi Selatan so that it can survive today with followers which is so much ?

The research objective was to map the influence of modality and to analyze the strategies for strengthening the modalities possessed by the caliphs and the followers of the Tarekat Khalwatiyah Samman, based in Patte'ne Marusu, Maros Regency, Sulawesi Selatan, so that they can survive to this day with so many tarekat followers.

Modality in society is defined as social capital, economic capital, symbolic capital and cultural capital. Pierre Bourdieu distinguishes three forms of capital, namely 
economic capital, social capital and cultural capital. Economic capital can be interpreted more broadly, covering material things having symbolic value as well as cultural capital which can include art, education, and forms of language. According to Bourdieu, capital acts as a social relation contained in an exchange system that can be expanded in the form of goods, both material and symbolic, without distinction which presents itself as something that is rare and worthy of being sought in a particular social formation[3]. Bourdieu's conception of capital theory cannot be separated from other concepts of domination, so that it is related to the concept of power, namely habitus and the realm (arena). Bourdieu builds his theory from a genetic structuralism paradigm that has the characteristics of internalizing externalities and internalizing internalities in terms of structure and agents. Bourdieu rejects the paradigmatic views of objectivity and subjectism, although not as a whole. Bourdieu is of the view that the position or power of an agent (individual or institution) in the social structure is determined by the capital it has [4].

Social capital becomes important, as expressed by Fukuyama who illustrates social capital in trust, believe, and vertrauen, meaning that the importance of trust is rooted in cultural factors such as ethics and morals[5]. Trust appears, then the community shares a set of moral values, as part of the way to create public expectations and honesty. Social capital is a tool for understanding social action, which involves the community and is formulated in various structures [6], [7]. Social capital is a "features of social organization such as networks, norms, and social trust that facilitate coordination and corporation for mutual benefits" (Putnam; 1993). Social capital also means (1) providing easy access to information for community members; (2) become a power sharing media; (3) developing solidarity; (4) enabling community resource mobilization; (5) enabling joint achievement, and (6) forming collective behavior and community organization[6]. Economic capital is defined as a resource that can be a means of production and a means of finance, which can be converted into types of economic capital such as the means of production (machinery, land, labor), material (income and objects), and money [8]. Economic capital is considered the most flexible and independent capital because it can easily be transformed into other domains or can be inherited.

Next is cultural capital, which is defined as an intellectual whole that can be produced through formal education and family heritage, such as the ability to present oneself in public, ownership of cultural objects, high value, certain knowledge and expertise from the results of formal education such as an education degree. Cultural capital is actually a belief in the values (values) regarding everything that is considered true and is always followed by efforts to actualize it. The relationship between cultural capital and this research is cultural capital in the form of intellectual qualifications of production results, which can be the ability to appear in public, ownership of cultural objects, knowledge and expertise, beliefs and values.

The strategies that Bourdieu offers to strengthen modalities in a society are (1) a biological investment strategy, which is a strategy that is closely related to the preservation of offspring and guarantees the inheritance of capital for future generations with the aim of preparing a better next generation; (2) successive strategy, namely the effort to pass on property to the next generation. The inheritance of assets is usually related to the inheritance of economic and cultural capital, (3) educational strategies, namely the efforts made by actors to produce new social actors who can skillfully inherit the capital owned by these actors, (4) economic invasion strategies or so-called also economic capital which has the aim of maintaining and increasing the economic capital that has been previously owned, and (5) a symbolic investment strategy, namely a strategy related to all acts of preserving symbolic capital, which aims to make an individual or a social group get legalization in his social life. This strategy is very important because it is related to a person's recognition of his position, the greater the symbolic capital he has, the greater its influence on other social groups [9]. The five modalities strategies will be used as an instrument to measure the extent to which the strengthening of the modalities possessed by the community in the Tarekat Khalwatiyah Samman community in Patte'ne Marusu, Maros Regency, Sulawesi Selatan so that it can survive with such a large community not only in Sulawesi Selatan but also in other regions. others even abroad such as Malaysia, Singapore and Brunei.

\section{METHOD}

This type of research is qualitative to map the modalities and to analyze the strategies for strengthening the modalities of the Patte'ne Marusu community, Maros Regency, Sulawesi Selatan Province, so that the Khalwatiyah Samman tarekat can survive with such a large number of followers. Approaching existing phenomena, taking place at this time or in the past, the data are qualitatively sourced from a broad and well-founded description, and contain an explanation of the processes that occur in the local scope [10].

This research was conducted in Patte'ne Marusu, Maros Regency, Sulawesi Selatan Province. The research subject was the leader (caliph) of the Khalwatiyah Samman Order and his followers. The selection of subjects was carried out by using purposive sampling technique, which is the sampling of data sources with certain considerations. Research subjects will be mapped based on the duties and roles of the leader (khalifah) and the institutional structure of the Khalwatiyah Samman Tarekat in Patte'ne Marusu, Maros Regency, Sulawesi Selatan Province.

The main instruments in this study were the researchers themselves and the research instruments compiled by the research team. This is because researchers act as planners, collectors of data and act as people who interpret the data obtained during the research process. Likewise, the research instrument was used to measure 4 modalities (economic, social, cultural, and symbolic capital) owned by the Khalwatiyah Samman Tarekat and 5 strategies to strengthen social modalities (strategies to strengthen biological investment modalities, successive, educational, and symbolic investment strategies) and supporting instruments. is an interview guide for use in in-depth interviews.

The collected data (heuristic) is then carried out selection (verification) or source criticism because each 
source has external aspects (true sources) and internal (provides information as needed) [11]. The results of verification or source criticism are followed by interpretation (interpretation) of facts, because facts are symbols or representations of something that has ever existed, has its own objective reality[12]. Data validation was carried out by extending observation techniques, increasing persistence, holding member checks, and triangulation [13]. The results of the interpretation are written (historiography) as the culmination of everything in the historical research method by trying to capture and understand history as it happens[14].

\section{RESULT AND DISCUSSION}

\section{A. Kampung Khalwatiah Samman Patte'ne Maros}

The position of Kampung Khalwatiyah Samman Maros is directly adjacent to the boundaries of Makassar City, about $2 \mathrm{~km}$ from the position of Sultan Hasanuddin Mandai Maros International Airport, Makassar or about 11 $\mathrm{km}$ from the center of Makassar City. Kampung Khalwatiyah Samman Patte'ne Marusu, Maros Regency, is very easy to reach, which is located at the end of the Sutami Toll road to Sultan Hasanuddin International Airport.

The inhabitants of Kampung Khalwatiyah Samman are predominantly ethnic / Bugis and in one village, namely Kampung Ujung Bulo, Takkalasi, SossoE and Mandai Makassar, are predominantly ethnic / ethnic Makassar. The people of TemmappaduaE Village are multi-ethnic, consisting of the dominant Bugis and Makassar ethnicities with the ability of the people to use the Bugis and Makassar languages equally well. Maros Regency is a highland area not far from the city of Makassar, the capital city of Sulawesi Selatan Province.

Patte'ne Village as the center of the development of the Khalwatiyah Samman Tarekat, as well as the Cultural Village, is developing rapidly in the warehouse area on the outskirts of Makassar City, so that slowly the community becomes heterogeneous due to the emergence of workers from various regions in Sulawesi Selatan who work in warehouses in the Patte area. ne. The development of the village was in line with the development of the Khalwatiyah Tarekat which was getting busier every year by its congregation, especially at the time of the maulid and meeting meetings between the followers of the Khalwatiyah Samman Tarekat in Patte'ne Maros.

\section{B. Gallarang in Marusu}

Tarekat Khalwatiyah Samman is the name of the Tarekat which is centered in Patte'ne Marusu Village or Patte'ne Marusu Cultural Village, Maros Regency, Sulawesi Selatan. Khalwatiyah comes from the name of a 17th century Sufi warrior ulama from Makassar, namely Sheikh Yusuf Al-Makassari Al-Khalwati (tabarruk) against Muhammad (Nur) Al-Khalwati Al Khawa Rizmi. The Khalwatiyah Samman Order is taken from the name of an 18th century Medina Sufi Muhammad Al-Samman. The Khalwatiyah Samman Order can develop in Indonesia because of its open nature, even though its teachings are closed. This tarekat combines the teachings of the Egyptian khalwatiyah tarekat with a number of new understandings extracted by Muhammad Al-Samman. According to Dara Nanda Vitera's [15] notes that in 1825, the Khalwatiyah Samman order arrived in the archipelago (Sulawesi Selatan) by Abdullah al-Munir.

According to Syakirin sources, Mustafa al-Bakri is not only a sheikh who studies religion, especially the Khalwatiyah Order but is also known as a writer with Sufi literary works whose content is related to his teachings. One of the literary works produced and known is Tasliyat Al-Ahsan.

There are several versions of the spread of the Khalwatiyah Samman Order to Sulawesi Selatan, including; The Khalwatiyah Order, which delivered through Sheikh Yusuf al-Makassari developed in Makassar and its surroundings; Tarekat Khalwatiyah Samman which delivered through Syekh al-Paembani from Abd. Al-Karim al-Sammani, this tarekat developed in Palembang and Maros Regency. Based on sources[15]-[17]. The Khalwatiyah Samman Congregation entered and spread in Sulawesi Selatan in 1825 AD $(1240 \mathrm{H})$ was developed by Sheikh Abdullah al-Munir from Sumbawa who studied with Sheikh Idris Bin Usman and Sheikh Idris Bin Usman studied from Sheikh Siddiq bin Umar Khan al-Madani and Sheikh Abdus Samad al-Palembani who were direct students of the founder of the Khalwatiyah Samman Order, namely Sheikh Muhammad Samman.

The basic teachings of the Khalwatiyah Order are (1) Yaqza, namely awareness of himself as a despicable creature before Allah the Almighty, (2) Taubah, namely asking for forgiveness for all sins, (3) Muhasabah, namely self-introspection, (4) Inabah, desiring to return to Allah, (5) Tafakkur, meditating on the greatness of Allah, (6) I'tisam, which is always acting as the caliph of Allah on earth, (7) Firar, which is running away from a wicked and useless worldly life, ( 8) Riyadah, train yourself to do as much charity as possible, (9) Tasyakur, always give thanks to Allah by serving and praising him, and (10) Sima, concentrating all members of the body in following Allah's commands, especially sensing.

The basic teachings of the Khalwatiyah Order are (1) Yaqza, namely awareness of himself as a despicable creature before Allah the Almighty, (2) Taubah, namely asking for forgiveness for all sins, (3) Muhasabah, namely self-introspection, (4) Inabah, desiring to return to Allah, (5) Tafakkur, meditating on the greatness of Allah, (6) I'tisam, which is always acting as the caliph of Allah on earth, (7) Firar, which is running away from a wicked and useless worldly life, ( 8) Riyadah, train yourself to do as much charity as possible, (9) Tasyakur, always give thanks to Allah by serving and praising him, and (10) Sima, concentrating all members of the body in following Allah's commands, especially sensing. 
Although he was born in Medina (Saudi Arabia) to a person known as Muhammad Bin Abd. Al_Karim Al Madani Al-Syafi'l Al-Samman (1130-1189 / 1718-1775) or better known as Al-Sammani or Muhammad Samman. The teachings of the Khalwatiyah Samman Tarekat, formulated by combining recitation-recitation techniques, and mystical teachings, the Khalwatiyah Samman Tarekat has so many followers, even though it has its own rituals to become followers. Followers must follow the initiation by reading bai'at, which is an oath of allegiance to the Shaykh to become his disciple with the consequence of having to follow the rules and regulations that have been officially stipulated in the tarekat, including his relationship with the sheikh.

The teachings of the Khalwatiyah Samman Order are carried out through Baiat or the recitation of an oath of allegiance which is conveyed by someone who wants to become a follower or member of the Khalwatiyah Order and when they have committed allegiance, they are considered as reborn from their previous life. Baiat is made a special requirement in entering and deepening the Khalwatiyah Samman Order for a student.

\section{Modalities and Strategies for Strengthening the Khalwatiyah Samman Order}

The modality referred to in this research is what kind of capital the Tarekat Khalwatiyah Samman has, which is based in Patte'ne Village, TemmapaduaE Village, Marusu District, Maros Regency, so that the tarekat can survive to this day. To review these questions, which are based on research data using the theoretical approach of Pieere Bourdieu on the form of capital, namely economic, symbolic, social, and cultural modalities. To find out the survival strategy of the Khalwatiyah Samman Order in strengthening modalities also uses Pieerre Bourdieu theory. [2], [18]

The research data shows that the Khalwatiyah Samman Order uses this modality, so that it can survive until today. Starting from social modality data. Social modality can be defined as the actual and potential resources a person has that comes from an institutionalized social network. The Khalwatiyah Samman Order is an institutionalized institution called the Khawatiyah Samman Tarekat. This tarekat has a very wide social network, almost all regions in Sulawesi Selatan, even to foreign countries such as Malaysia, Singapore and Brunei Darussalam, there are followers of the Khalwatiyah Samman Tarekat, as stated, one of the followers of the Khalwatiyah Samman tarekat, Usman;

Adherents of this tarekat, coming from various regions in Sulawesi Selatan, especially from the Bone, Wajo, Sidrap, and Soppeng areas, some even from Malaysia, every year during Maulid Besar in Patte'ne, gather for gathering (temmu year) which is coupled with Maulid, they came from these areas and gathered in this village, thousands and even tens of thousands came to visit to get together with their caliphs.

Based on the results of research, especially during the birthday of the Great Prophet Muhammad SAW, tens of thousands (64 thousand) of the followers of the Khalwatiyah Samman Tarekat gathered at Patte'ne Marusu, Maros Regency, Report of the maulid committee, 2019, as seen in the following picture:

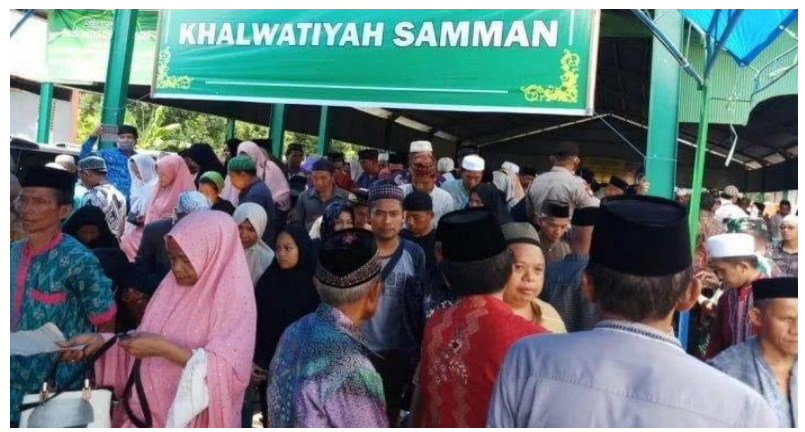

Figure 1: Adherents of the Khalwatiyah Samman Congregation Prepare to Perform Congregational Prayers at the Mosque Square (Photo: Salma, 17 November 2019)

Based on the results of research, especially during the birthday of the Great Prophet Muhammad SAW, tens of thousands (64 thousand) of the followers of the Khalwatiyah Samman Tarekat gathered at Patte'ne Marusu, Maros Regency, Report of the maulid committee, 2019, as seen in the following picture.

The social modalities of the Khalwatiyah Samman Tarekat are also reflected in the existence of aspects of values that are universally adopted, the value of maintaining and increasing welfare, the existence of traditions that contain aspects of respect, commitment, and acceptance of the tarekat. This tarekat creates general expectation and honesty because this community can share a set of moral values. The social modality of this tarekat is also illustrated by the ease in accessing information for its adherents, where every time the Caliphs visit their adherents in the form of congratulatory prayers either done in mosques or in the homes of the Khalwatiyah Samman community accompanied by joint dhikr. The Khalwatiyah Tarekat becomes a media with adherents to stay in touch to share goodness and happiness, as well as a vehicle for developing solidarity for mutual achievement to shape collective behavior in the Tarekat Khalwatiyah Samman community. The description of the social modalities of the Khalwatiyah Samman Order is illustrated in the following social activities:

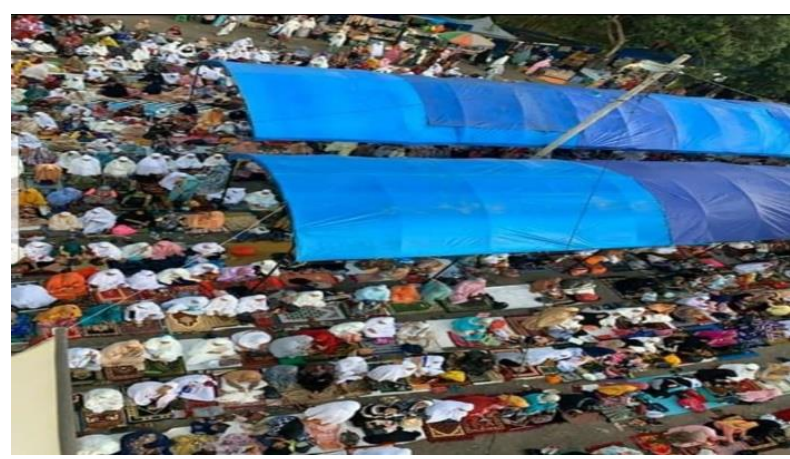


Figure 2: Jamaah Khalwatiyah Samman performs Congregational Prayers (Photo Documentation: Salma, 17 November 2019)

In connection with economic modalities, it is illustrated by the busy hospitality that is held every year. According to the narrative of one of the Jamaah Khalwatiyah Samman stated that "our family had the opportunity to visit Patte'ne to stay in touch directly with the Caliph for gratitude for our successful harvests so that we could attend the annual event in Patte'ne". The statement of a congregation described their coming to Kampung Patte'ne as the center of Khalwatiyah Samman as gratitude for its economic success.

Research on modalities and strategies for strengthening modalities for the Khalwatiyah Samman tarekat using the theoretical approach developed by Pieere Bourdieu. The modalities in society that are meant by Bourdieu are social, economic, symbolic and cultural capital. This modality acts as a social relation. Bourdieu is of the view that the position or power of an agent in the social structure is determined by the capitals it has, just as the Khalwatiyah Samman Order has modalities in its social structure so that it can survive until today.

Based on Bourdieu's view of the strategy of strengthening modality in society to survive, the Khalwatiyah Samman Tarekat, is more dominant in social and cultural strategies in strengthening its teachings so that it can develop and survive, in addition, undertaking strengthening strategies, namely biological investment strategies, strategies that are owned by strengthening on the aspect of preservation or inheritance for the next generation by better preparing the next generation; also carry out a successive strategy, namely passing on his teachings including culture for the next generation.

Based on Bourdieu's view of the strategy of strengthening modality in society to survive, the Khalwatiyah Samman Tarekat, is more dominant in social and cultural strategies in strengthening its teachings so that it can develop and survive, in addition, undertaking strengthening strategies, namely biological investment strategies, strategies that are owned by strengthening on the aspect of preservation or inheritance for the next generation by better preparing the next generation; also carry out a successive strategy, namely passing on his teachings including culture for the next generation.

\section{CONCLUSION}

Based on the results and discussion of the research, the following conclusions can be drawn. The modalities used by the Khalwatiyah Samman Order are social, economic, cultural and symbolic modalities. The determinants of the modalities used are social and cultural (symbolic) modalities. The strategy of strengthening the modalities of the Khalwatiyah Samman Order is based on strengthening biological investment, namely the strategy of preserving the teachings of the next generation by preparing better and more successful future generations, namely the inheritance of teachings and culture through friendship and congregational prayer from one place (village) to another. continuously so as to create a social contract between the leader and its followers directly.

\section{ACKNOWLEDGMENT}

We would like to extend highly appreciation to Universitas Negeri Makassar, the Faculty of Social Sciences for sponsoring the writing of this article and to the research informants, who provided valuable information in this research. Our warmest appreciation goes to Makassar State University, the Faculty of Social Sciences who sponsored this article and to the research informants who provided valuable information in this research.

\section{REFERENCES}

[1] C. Calhoun, "Habitus, field, and capital: The question of historical specificity," Bourdieu Crit. Perspect., vol. 1, no. 1, 1993.

[2] P. Bourdieu, "The forms of capital," in The Sociology of Economic Life, Third Edition, 2018.

[3] P. S. M. Ignasia, "Modalitas dalam Kontestasi Politik (Studi tentang Modalitas dalam Kemenangan Pasangan Hanny Sondakh dan Maximiliaan Lomban pada Pemilukada di Kota Bitung Sulawesi Utara Tahun 2010," Semarang, 2012.

[4] P. Bourdieu and L. J. D. Wacquant, An invitation to reflexive sociology. University of Chicago press, 1992.

[5] F. Fukuyama, Trust: The social virtues and the creation of prosperity, vol. 99. Free press New York, 1995.

[6] S. Bahri, "A'pa Aliri, Studi Penguatan Modal Sosial pada Masyarakat Matajang Kecamatan Maiwa Kabupaten Enrekang." Disertasi. Universitas Negeri Makassar, 2014.

[7] J. S. Coleman, "Social Capital in the Creation of Human Capital," Am. J. Sociol., 1988.

[8] P. D. Firmanzah, "Persaingan, Legitimasi, Kekuasaan, dan Marketing Politik," Jakarta Yayasan Obor Indones., 2010.

[9] S. R. Rusdiarti, "Bahasa, Kapital Simbolik dan Pertarungan Kekuasaan: Tinjauan Filsafat Sosial Pierre Bourdieu tentang Bahasa." Tesis Pascasarjana. Depok: Departemen Filsafat FIB,[tidak dipublikasikan], 2004.

[10] U. Silalahi, "Metode penelitian sosial." Unpar Press, 2006

[11] N. Notosusanto, Norma-norma dasar penelitian dan penulisan sedjarah. Pusat desjarah ABRI, Departemen PertahananKeamanan, 1971.

[12] L. Gottschalk, Mengerti Sejarah. Jakarta: UI Press, 1986.

[13] L. J. Moleong, "Metodologi Penelitian Kualitatif (Edisi Revisi)," in PT. Remaja Rosda Karya, 2017.

[14] S. M. A. R. Hamid, Pengantar Ilmu Sejarah. Makassar: Rayhan Intermedia, 2008.

[15] M. N. O. N. Seminar, "Tarekat Khalwatiyah Samman di Indonesia."

[16] C. Priandika, "Tantangan Generasi Muda Tarekat Khalwatiyah Samman di Patte'ne, Marusu Kabupaten Maros Pada Era Modernisasi," Sosioreligius, vol. 4, no. 1, 2019.

[17] A. A. Nurjaya, "Pesan Dakwah dalam Ajaran Tarekat Khalwatiyah Samman (Analisi Hermeneutika Paul Ricoeur)." Universitas Islam Negeri Alauddin Makassar, 2017.

[18] R. Jenkins, Pierre Bourdieu. 2014 